\title{
The Effects of Immunophenotyping with Flow Cytometry on Prognosis in Acute Lymphoblastic Leukemia
}

\section{Akut Lenfoblastik Lösemide Flow Sitometri ile İmmünofenotiplemenin Prognoz Üzerine Etkileri}

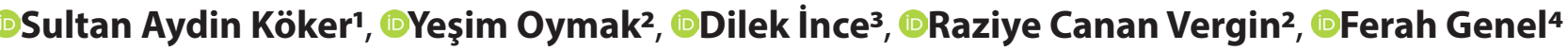 \\ 'Department of Pediatric Hematology and Oncology, Manisa City Hospital, Manisa, Turkey \\ 2Department of Pediatric Hematology and Oncology, Dr. Behçet Uz Children's Hospital, Izmir, Turkey \\ ${ }^{3}$ Department of Pediatric Oncology, Dokuz Eylül University School of Medicine, Izmir, Turkey \\ ${ }^{4}$ Department of Pediatric Immunology, Dr. Behçet Uz Children's Hospital, Izmir, Turkey
}

\begin{abstract}
Background: The identification of immunophenotype subgroups is very important for the diagnosis and prognosis of acute lymphoblastic leukemia (ALL).

Material and Method: The study is designed as a retrospective cohort study which included 105 children with ALL (65 males, 40 females; mean age $5.9 \pm 3.8$ years) who were treated TR-ALL 2000 (modified) BFM treatment protocol.

Results: The distributions of EGIL classification were pro-B ALL $(n=1)$, common B ALL $(n=46)$, pre-B ALL $(n=40)$, pre-T ALL $(n=8)$, cortical T ALL $(n=6)$, and mature T ALL $(n=4)$. Leukocyte $\geq 100,000 /$ $\mathrm{mm}^{3}$, lymphadenopathy $\geq 2 \mathrm{~cm}$, mediastinal involvement were commonly identified in T ALL group. T ALL had a poor response to chemotherapy according to 8th-day peripheral circulation blast counts and 15th-day bone marrow aspiration (BMA) blast counts. The recurrence, mortality, and death rate in the induction period of treatment were frequently detected in T ALL group. The variables that had prognostic potential, as indicated by univariate analyses, were leukocyte count, hepatomegaly, splenomegaly, and lymphadenopathy at the time of diagnosis, 8th-day steroid response, 15th-day BMA response, risk group, recurrence, and immunophenotyping. Multivariate Cox regression analysis demonstrated that only the leukocyte count (HR 2.51, p < 0.001) was a predictor of prognosis.
\end{abstract}

Conclusion: Immunophenotyping may be effective in the diagnosis and prognosis of ALL, identification of risk groups, and in risk-based treatment planning. T ALL had a poor prognosis.

Keywords: Flow cytometry, immunophenotyping, acute lymphoblastic leukemia, children
Öz

Giriş: Akut lenfoblastik löseminin (ALL) tanı ve prognozu için immünofenotip alt gruplarının tanımlanması çok önemlidir.

Gereç ve Yöntem: Çalışma, TR-ALL 2000 (modifiye) BFM tedavi protokolü ile tedavi edilen 105 ALL olgu (65 erkek, 40 kadın; ortalama yaş $5.9 \pm 3.8$ yı) içeren retrospektif kohort çalışması olarak tasarlanmıştı.

Bulgular: EGIL sınıflaması dağılımları pro-B ALL $(n=1)$, common B ALL ( $n=46)$, pre-B ALL $(n=40)$, pre-T ALL $(n=8)$, kortikal TALL ( $n=6)$ ve matür T ALL ( $n=4)$. T ALL grubunda lökosit $\geq 100.000 / \mathrm{mm}^{3}$, lenfadenopati $\geq 2 \mathrm{~cm}$, mediastinal tutulum yaygın olarak tespit edildi. $T A L L$, 8.gün periferik kan yaymasında blast sayısı ve 15. gün kemik iliği aspirasyonu (KIA)' nundaki blast sayısına göre kemoterapiye kötü yanıt gösterdiği saptandı. Tedavinin indüksiyon döneminde nüks, mortalite ve ölüm oranı T ALL grubunda sık olarak görüldü. Tek değişkenli analizle gösterilen prognostik potansiyele sahip olan değişkenler tanı anında lökosit sayısı, hepatomegali, splenomegali ve lenfadenopati, 8. gün steroid yanıtı, 15. gün KIA yanıtı, risk grubu, nüks ve immünofenotip idi. Çok değişkenli Cox regresyon analizinde ise sadece lökosit sayısının (HR 2.51, p <0.001) prognozu önemli derecede etkilediğini göstermiştir

Sonuç: İmmünofenotipleme ALL'nin tanı ve prognozunda, risk gruplarının tanımlanmasında ve riske baglı tedavi planlamasında etkili olabilir. T ALL tanısı alan hastalarda prognozun kötü olacağı gösterildi.

Anahtar Kelimeler: Akım sitometrisi, immünofenotipleme, akut lenfoblastik lösemi, çocuk

Corresponding (illetişim): Sultan Aydin Köker, Department of Pediatric Hematology and Oncology, Manisa City Hospital, Manisa, Turkey E-mail (E-posta): drsultanaydin@hotmail.com

Received (Gelis Tarihi): 28.08.2020 Accepted (Kabul Tarihi): 02.11.2020 


\section{INTRODUCTION}

Leukemia comprises nearly $25-30 \%$ of childhood malignancies. ${ }^{1}$ For acute lymphoblastic leukemia (ALL), previously known as a deadly disease, developments in diagnosis and treatment and advances in support treatments have achieved lengthened disease-free survival in most cases. In fact, $70-80 \%$ of cases have the chance of full recovery from the disease (cure). ${ }^{1,2}$

For pediatric ALL patients, for determination of both risk group and prognosis, the following factors are known; age, gender, leukocyte count, hematocrit value, platelet count, hepatomegaly, splenomegaly, lymphadenopathy presence, MSS involvement, testis involvement, mediastinal mass, and other extramedullary involvement, French-AmericanBritish (FAB) classification ( $L 1, L 2, L 3)$, response to treatment, the molecular genetics such translocations, and the Minimal Residual Disease (MRD) status is defined by qPCR or NGS. Additionally, in recent times immunophenotyping results obtained by investigation of cytogenetic and molecular genetic disorders with flow cytometry have gained importance..$^{3-6}$

The study aims to research the properties and effect on the prognosis of ALL immunophenotype subgroups and the evaluation of correlations between clinical and other laboratory data identified during the diagnosis stage.

\section{MATERIAL AND METHOD}

The study included 105 cases with ALL diagnosed in Pediatric Hematology and Oncology Department and treated with TRALL2000 (modified) BFM protocol,followed up between January 2008 to March 2012. The study is designed as retrospective cohort study. The patients' gender, age at diagnosis, leukocyte count, hematocrit value, platelet count, hepatomegaly, splenomegaly, lymphadenomegaly, central nervous system (CNS) involvement, testis involvement, mediastinal mass and other extramedullary involvement, French-AmericanBritish (FAB) classification (L1, L2, L3), immunophenotyping with flow cytometric investigation, translocations (t $(4 ; 11)$, t $(9 ; 22)$, t $(12,21), t(1 ; 19)), 8^{\text {th }}$-day prednisone response, and $15^{\text {th }}$-day and $33^{\text {th }}$-day bone marrow aspiration (BMA) blast rates, risk groups, surveillance duration, relaps, and mortality were retrospectively obtained from patients' medical records. The study was approved by the local Ethics Committee of Dr. Behçet Uz Children's Hospital in accordance with the Helsinki Declaration (Project Number: 2012/47). Informed consent was obtained from each parent and/or patients.

Mediastinal involvement was assessed by thorax radiography (P/A and lateral). Central nervous system (CNS) involvement was defined as presence of leukemic cells in cerebrospinal fluid (CSF) with lumbar puncture and findings by Magnetic Resonance Imaging (MRI). Abdominal ultrasonography was investigated organomegaly, renal involvement, mass, and lymphadenopathy. Hepatomegaly was defined as $\geq 2 \mathrm{~cm}$ liver palpation at the right mid costal margin, splenomegaly was defined as $\geq 2 \mathrm{~cm}$ enlargement of the spleen in the left upper quadrant on physical examination. Testis involvement was evaluated by testis ultrasonography for all male patients.

Cytogenetic, FISH and molecular investigations examined in aspiration material and $\mathrm{t}(9 ; 22), \mathrm{t}(1 ; 19), \mathrm{t}(4 ; 11)$, and $\mathrm{t}$ $(12 ; 21)$ translocations were evaluated at the Gentest Genetic Laboratory in Özel Şifa Hospital.

Prednisone response is explained as the peripheral blast count on day 8 of treatment. Prednisone good response (PGR) was characterized by $<1,000 / \mu \mathrm{L}$, while prednisone poor response (PPR) showed $\geq 1,000 / \mu \mathrm{L}$ peripheral blast count on 8thday treatment. Response in BM was evaluated on 15th-day and 33th-day of induction treatment and was classified as M1 (<5\%), M2 (5 to <25\%), and M3 ( $\geq 25 \%$ leukemic blasts). Complete remission (CR) was described as M1 BM on day 33 of induction therapy, the absence of leukemic blasts in blood and CSF, and no symptom of local disease. Relapse was characterized by recurrence of $25 \%$ lymphoblasts or over in BM or local leukemic involvements at any site.

Risk group stratification is categorized three groups; patients with initial leukocyte count $<20,000 / \mathrm{mm}^{3}$ and age $\geq 1$ and $<$ 6 years, and blast counts $<1,000 / \mathrm{mm}^{3}$ in peripheral blood on $8^{\text {th }}$-day after 7 day prednisolone and IT MTX treatment, no T cell immunology, $t(9 ; 22)(B C R / A B L)$ and $t(4 ; 11)$ (MLL/AF4) negative and $\mathrm{M} 1$ on 33th-day were defined as standard risk group (SRG).

The patients with initial leukocyte count $\geq 20,000 / \mathrm{mm}^{3}$ or age $<1$ or $\geq 6$ years, and blast counts $<1,000 / \mathrm{mm}^{3}$ in peripheral blood on $8^{\text {th }}$-day after 7 day prednisolone and IT MTX treatment, $\mathrm{t}(9 ; 22)(\mathrm{BCR} / \mathrm{ABL})$ and $\mathrm{t}(4 ; 11)$ (MLL/AF4) negative on 33th-day, were described as moderate risk group (MRG).

The cases with blast counts $\geq 1000 / \mathrm{mm}^{3}$ on $8^{\text {th }}$-day in peripheral blood, $t(9 ; 22)$ (BCR/ABL) and $t(4 ; 11)$ (MLL/AF4) positive, without full remission on $33^{\text {th }}$-day, with hypodiploidy (chromosome $<45$ ) chromosome anomaly, and presence of each criteria alone independent of age and leukocyte count (one criterion is sufficient) were characterized as high risk group (HRG). ${ }^{6}$

\section{Flow cytometry}

Immunophenotyping assays were administered by four-color [FITC (Fluorescein Isothiocyanate), PE (Phycoerythrin), PC5 (Phycoerythrin-Cyanine 5) or PC7 (Phycoerythrin-Cyanine 7)] flow cytometry analysis of BM samples. Cytoplasmic and surface cell markers were identified using according to Immunological Characterization of Leukemia (EGIL) classification. ${ }^{7}$

The reactivity with fluorescent-conjugated monoclonal antibodies (Moab) was against T-cell-related antigens (CD1a, CD2, CD3, CD4, CD5, CD7, and CD8), B-cell differentiation markers (CD10, CD19, CD20, CD22, CD79a), myeloid cell antigens (CD11b, CD13, CD14, CD15, CD33, CD117, and Moab anti myeloperoxidase [MPO]), nonlineage restrict molecules (nuclear enzyme TdT, CD45, HLA-Dr, CD34), and also Moab against IgM heavy chains (mü chain) and light chains of immunoglobulins ( $\kappa$ and $\lambda$ ). The B cell ALL group was classified as pro-B cell ALL, common B cell ALL, pre-B cell ALL, 
and mature $B$ cell ALL. According to subtypes of B-cell ALL, pro-B cell $A L L$ was defined as positive CD19, CD22, CD34, and negative CD10, cytoplasmic and surficial lgM. Common B ALL was described as positive CD19, CD 22, CD10. Pre-B cell ALL group was characterized by positive CD19, CD22, CD10, су $\mu$, and negative slgM. Mature $B$ cell ALL was defined as positive CD10, CD19, CD20, CD22, cy $\mu$, and slgM. In addition, T cell ALL were separated into four subtypes as pro-T cell ALL, pre-T cell ALL, thymic (cortical) T cell ALL, and mature $T$ cell ALL according to EGIL classification. Pro-T cell ALL was defined as positive cytoplasmic CD3, CD7, TdT, and negative CD2, CD1a. Pre-T cell ALL was identified as positive cytoplasmic CD3, CD7, TdT, CD2, and negative CD1a. Cortical T cell ALL was described as positive cytoplasmic CD3, CD5, CD7 and CD1a. Mature T cell ALL group was defined as positive CD5, CD7, and negative CD1a with surface CD3 expression.? Immunophenotyping results were assessed as positive when at least $20 \%$ of cells were positive for all Moab. ${ }^{8}$

BM samples were studied in EDTA tubes. The white blood cell count was examined and diluted to $10,000-15,000$ cells in $1 \mathrm{ml}$. The dilution process used isotonic fluid. Each tube had antibodies inserted using different pipettes. After adding the antibodies, the bone marrow diluted to 100 microliters was added. After ensuring good mixing of antibody and bone marrow, tubes were incubated at room temperature in a dark place for 20 minutes. After the incubation duration, tubes obtained with the full blood lysis method had 500 microliters of Optilyse-C fluid added and they were mixed for a few seconds. They were left for incubation in the dark at room temperature for 10 minutes. The tubes then had 500 microliters isotonic fluid added and were incubated at room temperature and protected from light.

Statistical analysis: The obtained data were recorded on an assessment form. All statistical analyses were performed with the aid of SPSS 21.0 for Windows program. Descriptive statistics of data used mean, standard deviation, proportion and frequency values. Variables distribution was checked with the Kolmogorov Smirnov test. The quantitative data were analyzed with ANOVA test. For analysis of qualitative data, the chi-square test was used and the Fisher test if chi-square conditions were not provided. Kaplan-Meier and Cox regression analysis were used for survival analysis. P-value $<0.05$ was considered as significant.

\section{RESULTS}

\section{Demographic features}

This study included 105 patients (40 female, 65 male) with ALL. The mean age was $5.9 \pm 3.8$ years. The distribution of demographic characteristics at all patients according to EGIL classification is given in Table 1. Only one patient was pro-B cell ALL (4 years old). While the mean age at diagnosis was $5.1 \pm 3.5$ years, and $5.5 \pm 3.6$ years in Common-B cell ALL, and pre-B cell ALL, the mean age at diagnosis was $9.1 \pm 2.6$ years, $7.3 \pm 6.0$ years, and $10.5 \pm 3.1$ years in pre-T ALL, cortical T-ALL, and mature T-ALL, respectively. 13 (72.2\%) patients with T-cell ALL were diagnosed above 6 years $(p=0.001)$. Table 2 was showed the distributions of age, and gender in immunophenotypes groups among ALL patients. The mean surveillance duration in T-cell ALL was $25.6 \pm 18.8$ months and was shorter despite not statistically significant (Table 2).

\section{Clinical and Laboratory characteristics}

Patients with T cell ALL showed higher levels of leukocyte counts $(p=0.001)$. Especially, leukocyte counts on admission were found above $100.000 / \mathrm{mm}^{3}$ in patients with T cell ALL $(p<0.05)$ (Figure 1).

Lymphadenopathy above $2 \mathrm{~cm}$ highly occurred in the T cell ALL groups than common B cell ALL and pre-B cell ALL groups $(p<0.001)$ (Figure 2). At admission, extramedullary involvement was identified in 29 patients. Of theme, 11 cases had mediastinal involvement, eight cases had CNS involvement and four cases had testis involvement. Of three patients with CNS involvement were one retinal involvement, and three facial paralysis. T cell ALL group significantly highly suffered from mediastinal involvement $(p<0.05)$. Mediastinal involvement was not identified in pre-B cell ALL cases. There were no significant differences between the immunophenotype subgroups in terms of extramedullary involvement besides mediastinal involvement (Table 3).

Table 1. Distribution of demographic characteristics at all patients according to immunophenotype subgroups

\begin{tabular}{lccccc} 
& \multicolumn{2}{c}{ B-ALL } & \multicolumn{3}{c}{ T-ALL } \\
\cline { 2 - 6 } & $\begin{array}{c}\text { Common } \\
\text { B-ALL }\end{array}$ & $\begin{array}{c}\text { Pre-B } \\
\text { ALL }\end{array}$ & $\begin{array}{c}\text { Pre-T } \\
\text { ALL }\end{array}$ & $\begin{array}{c}\text { Cortical } \\
\text { T-ALL }\end{array}$ & $\begin{array}{c}\text { Mature } \\
\text { T-ALL }\end{array}$ \\
\hline Case numbers & 46 & 40 & 8 & 6 & 4 \\
Incidence (\%) & $44 \%$ & $38 \%$ & $7.5 \%$ & $5.5 \%$ & $4 \%$ \\
Gender (M/F) (n) & $31 / 16$ & $20 / 20$ & $6 / 2$ & $5 / 1$ & $3 / 1$ \\
Age (year) & $5.1 \pm 3.5$ & $5.5 \pm 3.6$ & $9.1 \pm 2.6$ & $7.3 \pm 6.0$ & $10.5 \pm 3.1$ \\
\hline
\end{tabular}

Table 2. Age, gender and surveillance duration in immunophenotype groups

\begin{tabular}{|c|c|c|c|c|c|c|}
\hline & & $\begin{array}{c}\text { Total }(n=105) \\
\text { N (\%)/ Mean } \pm \text { SD }\end{array}$ & $\begin{array}{c}\text { Common B-ALL }(n=47) \\
N(\%) / \text { Mean } \pm \text { SD }\end{array}$ & $\begin{array}{l}\text { Pre-B ALL }(n=40) \\
N(\%) / \text { Mean } \pm \text { SD }\end{array}$ & $\begin{array}{c}\text { T-ALL }(n=18) \\
\text { N (\%)/ Mean } \pm \text { SD }\end{array}$ & $\mathbf{p}$ \\
\hline \multirow{2}{*}{ Age } & $1-6$ years & $70(66.7 \%)$ & $35(74.5 \%)$ & $30(75.0 \%)$ & $5(27.8 \%)$ & \multirow{2}{*}{0.001} \\
\hline & $>6$ years & $35(33.3 \%)$ & $12(25.5 \%)$ & $10(25.0 \%)$ & $13(72.2 \%)$ & \\
\hline \multirow{2}{*}{ Gender } & male & 65 (61.9\%) & $31(66.0 \%)$ & $20(50.0 \%)$ & $14(77.8 \%)$ & \multirow{2}{*}{0.098} \\
\hline & female & $40(38.1 \%)$ & $16(34.0 \%)$ & $20(50.0 \%)$ & $4(22.2 \%)$ & \\
\hline \multicolumn{2}{|c|}{$\begin{array}{l}\text { Surveillance duration } \\
\text { (months) }\end{array}$} & $32.9 \pm 18.8$ & $31.9 \pm 17.9$ & $36.9 \pm 18.9$ & $25.6 \pm 18.8$ & 0.097 \\
\hline
\end{tabular}




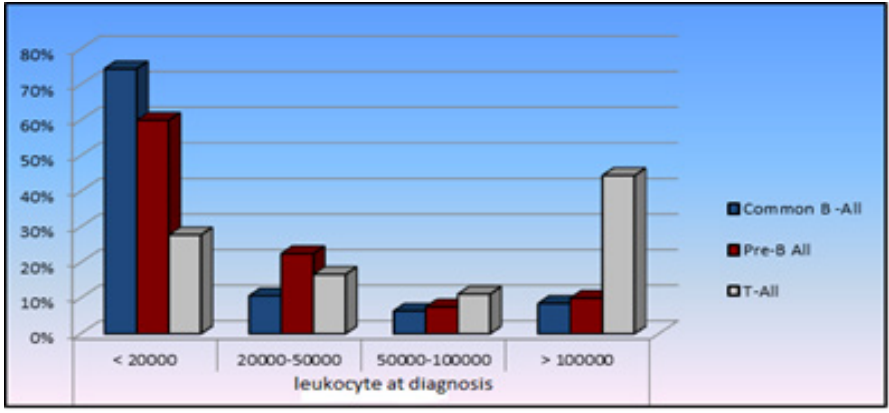

Figure 1. Distribution of leukocyte counts at time of diagnosis in ALL immunophenotype

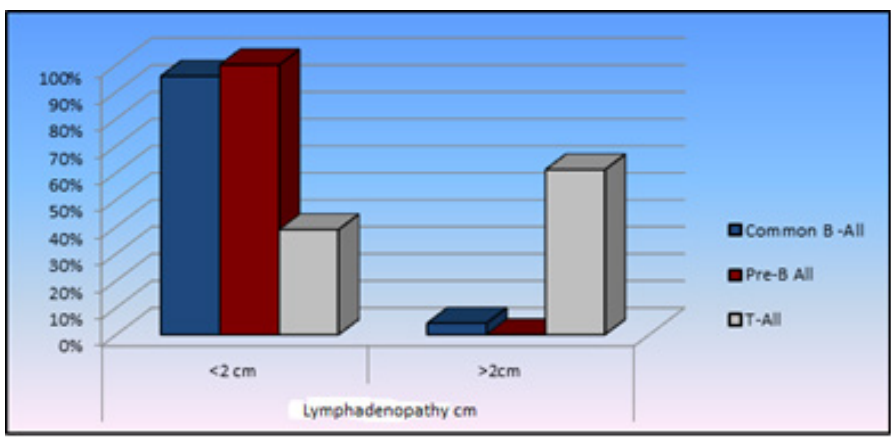

Figure 2. Distribution of lymphadenopathy in ALL immunophenotypes groups
While PPR on $8^{\text {th }}$-day and M3 on 15th-day BMA more often occurred in T-cell ALL groups, M3 on 33th-day BMA was similar between all immunophenotype subgroups (Table 4).

When 91 patients with cytogenetic investigation performed are investigated, $38.5 \%$ (35 patients) were identified to have cytogenetic anomalies. When the literature is investigated in terms of cytogenetic anomalies $t(12 ; 21)$ translocation is defined as having good prognosis, while $t(1 ; 19), t(4 ; 11)$ and t $(9 ; 22)$ groups have poor prognosis. As a result, translocation results were evaluated by separated into two groups. Translocation distribution was no significant difference among immunophenotype subgroups ( $\mathrm{p}=0.246$ ).

Of the 105, 11 (10.5\%) patients was not follow-up, 16 (17.0\%) had mortality. When evaluated according to immunophenotype subgroups, 5 (10.6\%) common B cell ALL, 5 (12.5\%) pre-B cell ALL, and 6 (33.3\%) T cell ALL patients were observed mortality. The mortality rate in the T cell ALL group was significantly higher than in the common B cell ALL and pre-B cell ALL groups $(p=0.036)$ (Table 5).

The general relapse rate of all patients was identified as 13.6\% (12 cases). When relapse is evaluated among immunophenotype subgroups, the relapse rate was $8.5 \%$ in the common B cell ALL group and $7.5 \%$ in the pre-B cell ALL group, while it was found to be statistically significantly high at $27.8 \%$ in the T cell ALL group $(p<0.05)$. Even though mortality was observed in $41.7 \%$ of cases who had a relapse, $2.6 \%$ of cases who had not relapse died.

Table 3. Extramedullary involvement in ALL immunophenotypes

\begin{tabular}{|c|c|c|c|c|c|c|c|c|}
\hline & & \multicolumn{2}{|c|}{ Common B-ALL $(n=47)$} & \multicolumn{2}{|c|}{ Pre-B-ALL $(n=40)$} & \multicolumn{2}{|c|}{ T-ALL $(n=18)$} & $\mathbf{p}$ \\
\hline Mediastinal involvement & CNS1 & 42 & $89.4 \%$ & 37 & $92.5 \%$ & 15 & $83.3 \%$ & \\
\hline $\begin{array}{l}\text { CNS } \\
\text { involvement }\end{array}$ & CNS3 & 3 & $6.4 \%$ & 3 & $7.5 \%$ & 2 & $11.1 \%$ & \\
\hline Testis involvement & & 3 & $9.7 \%$ & 0 & $0.0 \%$ & 1 & $7.1 \%$ & $P>0,05$ \\
\hline
\end{tabular}

Table 4. Treatment response in ALL immunophenotypes

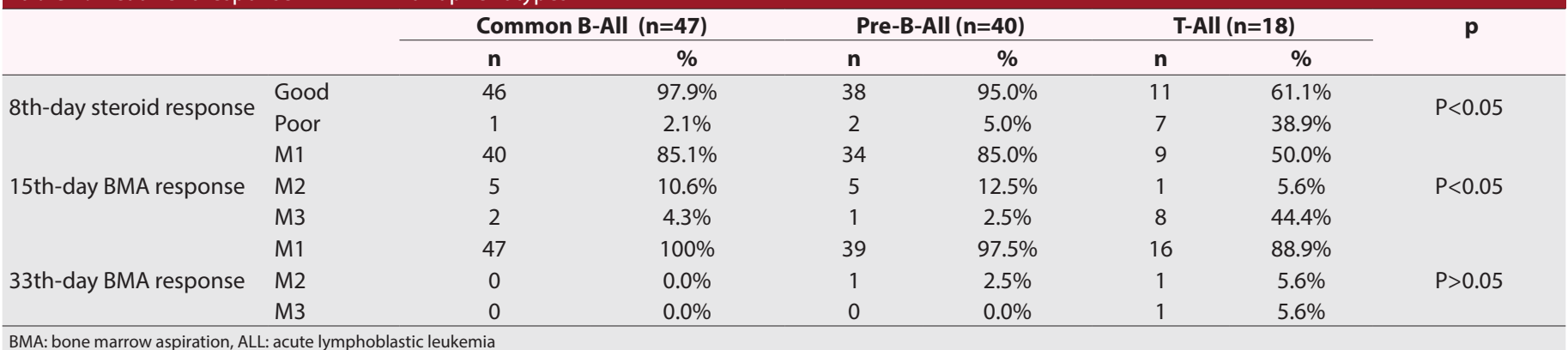

Table 5. Surveillance outcomes for ALL immunophenotypes

\begin{tabular}{|c|c|c|c|c|c|c|c|c|}
\hline & & \multicolumn{2}{|c|}{ Common B-ALL $(n=47)$} & \multicolumn{2}{|c|}{ Pre-B-ALL $(n=40)$} & \multicolumn{2}{|c|}{ T-ALL $(n=18)$} & \multirow[t]{2}{*}{$\mathbf{p}$} \\
\hline & & $\mathbf{n}$ & $\%$ & $\mathbf{n}$ & $\%$ & $\mathbf{n}$ & $\%$ & \\
\hline FInal status & Survival & 35 & $74.5 \%$ & 34 & $85.0 \%$ & 9 & $50.0 \%$ & 0.036 \\
\hline Death in induction & Yes & 2 & $4.3 \%$ & 2 & $5.1 \%$ & 2 & $11.8 \%$ & $P>0.05$ \\
\hline
\end{tabular}


There was no statistically significant difference between the event free survival (EFS) and the overall survival (OS) rates in the common B ALL, pre-B ALL and T ALL groups (Kaplan Meier log rank $p=0.103, p=0.05$, respectively). The EFS rates are shown in Table 6. But 3 years EFS and 5 years EFS more lowly occurred 55\%, 55\% in T cell ALL groups, respectively. 3 years OS was found $63 \%$ in T cell ALL groups (Table 7). When OS analyzed between the common B ALL and T cell ALL groups, and between the pre-B ALL and T cell ALL groups, statistically significant differences were identified (Kaplan Meier logrank, $p=0.03, p=0.038$, respectively). There was no statistically significant difference between the OS rates in the common $B$ ALL and pre-B ALL groups (Kaplan Meier log-rank $p=0.936$ ) (Figure 3).

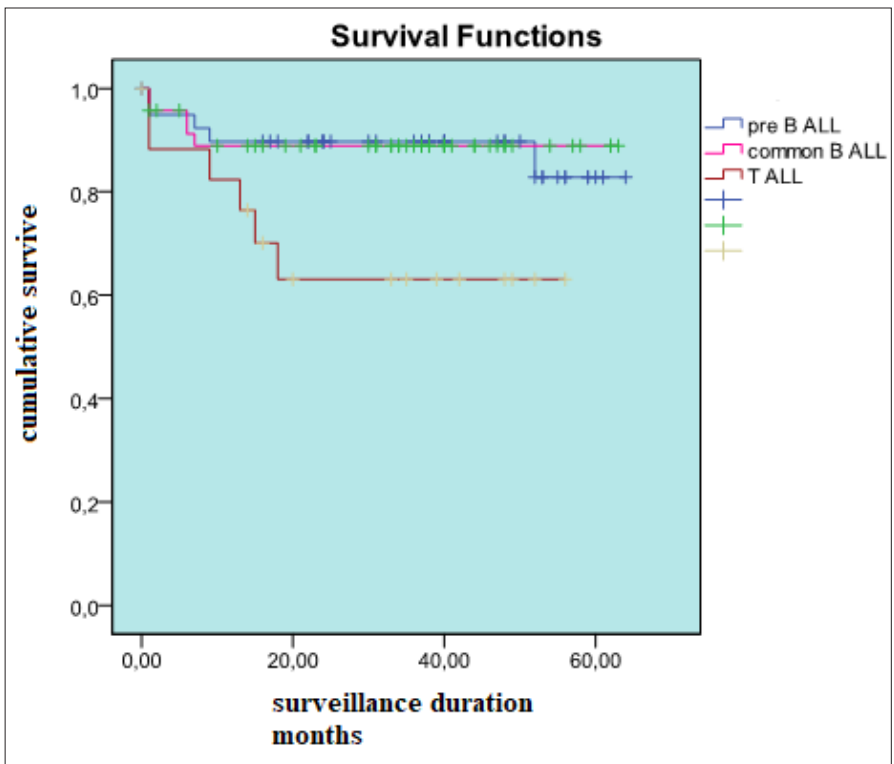

Figure 3. Overall survival rates according to immunophenotype subgroups (Kaplam-Meier curve)

Table 6. Event-free survival (EFS) of cases according to immunophenotype subgroups

\begin{tabular}{|c|c|c|c|c|c|c|}
\hline & & \multirow{2}{*}{ n count } & \multirow{2}{*}{ Median event duration } & \multicolumn{2}{|c|}{ EFS } & \multirow[t]{2}{*}{$\mathbf{p}$} \\
\hline & & & & 3 year EFS & 5 year EFS & \\
\hline & Common B -ALL & 47 & 34 months (1-63 months) & $80 \%$ & $69 \%$ & \\
\hline & T-ALL & 18 & 19 months (0-56 months) & $55 \%$ & $55 \%$ & \\
\hline
\end{tabular}

Table 7. Overall survival (OS) of cases according to immunophenotype subgroups

\begin{tabular}{|c|c|c|c|c|c|c|}
\hline & & \multirow{2}{*}{ n count } & \multirow{2}{*}{ Median surveillance duration } & \multicolumn{2}{|c|}{ Overall survival rate } & \multirow{2}{*}{$\mathbf{p}$} \\
\hline & & & & 3 year OS & 5 year OS & \\
\hline \multirow{4}{*}{ Immunophenotype } & Common B -ALL & 47 & 35 months (1-63 months) & $89 \%$ & $89 \%$ & \multirow{4}{*}{0.050} \\
\hline & Pre-B ALL & 40 & 39 months (0.5-64 months) & $90 \%$ & $83 \%$ & \\
\hline & T-ALL & 18 & 19 months (0.5-56 months) & $63 \%$ & - & \\
\hline & Total & 105 & 36 months (0-64 months) & $85 \%$ & $81 \%$ & \\
\hline
\end{tabular}

Kaplan Meier, ALL: acute lymphoblastic leukemia

\section{Logistic regression analysis results}

A univariate model found the effect of leukocyte count at the time of diagnosis, hepatomegaly, splenomegaly, lymphadenopathy presence, 8 th-day steroid response, $15^{\text {th }}$ day $\mathrm{BMA}$ response, risk group, immunophenotyping and recurrence development were significant for the patients survival $(p<0.05)$. The univariate model found no significant effect for age, gender, hematocrit value, platelet value, CNS involvement, cytogenetic anomaly presence, and $33^{\text {th }}$-day BMA response ( $p>0.05)$ (Table 8).

The multivariate model revealed that only leukocyte value had an effect on survival, while all other variables remained insignificant (Table 8).

\section{DISCUSSION}

In the early period of development, lymphoid cells differentiate to lymphocytes by migrating from bone marrow to the lymph glands, spleen, and thymus. Thus, leukemia develops as a result of problems occurring for a variety of reasons at any stage of these differentiation steps. At the same time, uncontrolled proliferation of mutant cells forming as a result of some mutations may be responsible for the pathogenesis. ${ }^{8}$

European BFM study group reported that the distribution of immunophenotypes was $86 \%$ precursor B-ALL and $14 \%$ T-ALL rates. ${ }^{10}$ Besides $83 \%$ of patients in our study were diagnosed with $B$ cell $A L L, 17 \%$ of patients were diagnosed with T cell ALL. T cell ALL incidence rate in our study is similar to the $7.3 \%$ to $16 \%$ rates reported in the literature. ${ }^{1}$ Blastic cells are in common B cell phenotype for most of the ALL patients. Moreover, the rate for common B cell ALL observed $51.6 \%$ in several studies. ${ }^{11}$ Most of our ALL patients (44\%) had common B cell ALL phenotype consistent with the literature. In addition, Scrappe et al. showed that immunophenotypes were characterized by $6 \%$ pro-B ALL, nearly $75 \%$ common $B$ cell ALL, and 19\% pre-B cell ALL. ${ }^{12}$ 
Table 8. Evaluation of the effects of all variables on survival

\begin{tabular}{|c|c|c|c|c|}
\hline \multirow{2}{*}{ Univariate model } & \multirow{2}{*}{ H.R } & \multicolumn{2}{|c|}{$\mathbf{9 5 \%}$ confidence interval } & \multirow{2}{*}{$\mathbf{p}$} \\
\hline & & Minimum & Maximum & \\
\hline Age & 1.04 & 0.91 & 1.19 & 0.526 \\
\hline Sex & 1.00 & 0.36 & 2.74 & 0.994 \\
\hline Leukocyte count & 2.51 & 1.65 & 3.81 & $<0.001$ \\
\hline Hematocrit & 1.18 & 0.34 & 4.15 & 0.794 \\
\hline Platelets & 0.53 & 0.26 & 1.10 & 0.087 \\
\hline Splenomegaly & 1.90 & 1.05 & 3.44 & 0.035 \\
\hline CNS Involvement & 1.58 & 0.79 & 3.19 & 0.197 \\
\hline Cytogenetics & 0.99 & 0.12 & 8.48 & 0.993 \\
\hline 8th day steroid response & 7.18 & 2.59 & 19.88 & 0.000 \\
\hline 15th day BMA response & 2.65 & 1.55 & 4.52 & 0.000 \\
\hline Immunophenotyping & 5.52 & 1.7 & 12.8 & 0.004 \\
\hline \multicolumn{5}{|l|}{ Multivariate reduced model } \\
\hline Leukocyte count & 2.51 & 1.65 & 3.81 & $<0.001$ \\
\hline
\end{tabular}

While the Turkish BFM study group reported that the male/ female (M/F) ratio in TR-ALL BFM 2000 protocol was 1.2 (28), $\mathrm{M} / \mathrm{F}$ ratio in developed countries was $1 / 1.2 .^{13,14}$ In our study, the $M / F$ ratio was identified $1.6 / 1$ and was observed to be similar to recent studies. A study in Brazil by Rego et al. described that the M/F ratio in T cell ALL cases was 4.2/1 and highly dominated by males. ${ }^{15}$ In this study, the $M / F$ ratio in $T$ cell ALL cases was 3.5/1, similarly the literature.

Scrappe et al. showed that the median age of 2178 cases was 4.6 years. ${ }^{12}$ In addition, Noronha et al. ${ }^{11}$ reported that the median age of T cell ALL cases was 8 years. The mean age of our patients was $5.9 \pm 3.8$ years, the mean age of $T$ cell ALL cases also was $8.8 \pm 4.1$ years.

Leukemia in children with T cell ALL usually presents with hyperleukocytosis. 18\% of precursor B ALL cases had leukocyte count $>50,000 / \mathrm{mm}^{3}$, while $51.4 \%$ of T cell ALL cases had leukocyte count $>50,000 / \mathrm{mm}^{3} .{ }^{16}$ Noronha et al. ${ }^{11}$ reported hyperleukocytosis in $81 \%$ of T cell ALL cases. Our study showed $50 \%(8 / 16)$ of our patients had WBC $>100000 / \mathrm{mm}^{3}$ at the time of diagnosis.

Patients with $\mathrm{T}$ cell ALL usualy present with hepatosplenomegaly and extramedullary involvement. ${ }^{17}$ Physical examination of our patients, $61.1 \%$ of $T$ cell ALL group revealed lymphadenopathy above $2 \mathrm{~cm}$. Schrappe et al. ${ }^{12}$ reported $8.1 \%$ mediastinal involvement at the time of diagnosis, $10.5 \%$ of our patients were observed similarly. In addition, most of mediastinal involvement usually present in the T cell ALL patients. ${ }^{14}$ In our study, the mediastinal involvement was $50 \%$ of T cell ALL despite $4.3 \%$ of common $B$ cell ALL cases.
$61.1 \%$ of T cell ALL cases were PPR, against $97.9 \%$ of common $B$ cell $A L L$, and $95 \%$ of pre-B ALL cases were PGR in the 8thday steroid response. ${ }^{18}$ In our study, 38.9 of T cell ALL cases were PPR in the $8^{\text {th }}$-day steroid response. Our study showed that patients with $T$ cell ALL respond well to chemotherapy in the 8th-day steroid response.

The recently study determined M1 in $61.9 \%$ and $M 3$ in $11.6 \%$ of precursor B cell, in spite of M1 in 55.1\% and M3 in $25.3 \%$ in $T$ cell ALL according to immunophenotype subgroup in $15^{\text {th }}$ day BMA response. ${ }^{19}$ Our results showed that $M 3$ had a higher rate in T cell ALL patients in the $15^{\text {th }}$-day BMA response.

Relapse occurs for almost high rates in patients with $T$ cell ALL. Patients with relapse had a short survival duration. ${ }^{12}$ Simultaneously, mortality consisted of T cell phenotype for most of the patients with ALL. ${ }^{17}$ Most of our T cell ALL patients had relapse, death during induction treatment, and mortality as consistent with the literature.

Six-year EFS rate was observed $80.2 \%$ of precursor B ALL and $74.8 \%$ of $\mathrm{T}$ cell ALL in a study investigating 2169 pediatric cases received ALL-BFM 95 protocol in Austria. ${ }^{20}$ 6-year EFS rates were identified as $77.5 \%$ at T cell ALL patients $(n=121)$ treated with BFM protocol from 1989 to $1998 .{ }^{21}$ In our study, the 3-year EFS and 5-year EFS was $80 \%, 69 \%$ in the common $B$ cell ALL group, respectively. In the pre-B cell ALL group, both 3-year EFS and 5-year EFS were similarly 77\%. Despite the statistically not significant differences between EFS rates in the immunophenotype subgroups, 3-year EFS in T cell ALL group had lower rates (55.0\%) compared to the other two groups. In addition, our study reported overall the prognosis of T cell ALL group was poor. 


\section{CONCLUSION}

T cell ALL is associated with male gender, old age, high leukocyte counts, extramedullary involvement such as mediastinal mass or CNS involvement. Leukocyte counts, hepatomegaly, splenomegaly, lymphadenopathy, $8^{\text {th }}$ day steroid response, $15^{\text {th }}$-day BMA response, risk group, immunophenotype, and relapse were significantly related to prognosis. EFS and OS in patients with T cell ALL were lower than $B$ cell ALL. T cell ALL is linked to poor prognosis.

The limitations of our study were a single-center experience, retrospective cohort study, low numbers of T cell ALL patients, short duration of follow up for evaluating EFS and OS and did not include $<1$-year-old patient.

\section{ETHICAL DECLARATIONS}

Ethics Committee Approval: The study was approved by the local Ethics Committee of Dr. Behçet Uz Children's Hospital in accordance with the Helsinki Declaration (Project Number: 2012/47).

Informed Consent: All patients signed the free and informed consent form.

Referee Evaluation Process: Externally peer-reviewed.

Conflict of Interest Statement: The authors have no conflicts of interest to declare.

Financial Disclosure: The authors declared that this study has received no financial support.

Author Contributions: Accumulation of data: Sultan Adın Köker, data analysis/interpretation: Yeşim Oymak, Ferah Genel, statistical analysis: Dilek Ince, Yeşim Oymak, supervision or mentorship: Raziye Canan Vergin, Ferah Genel

\section{REFERENCES}

1. Lanskowsky P. Leukemias. In: P. Lanzkowsky (ed). Manual of Peadiatric Hematol and Oncol 4th ed. Elsevier Academic Press. San Diego 2005: 41553.

2. Gurney JG, Severson RK, Davis S et al. Incidence of cancer in children in the United States. Sex-, race-, and 1-year age-specific rates by histologic type. Cancer 1995; 75: 2186-95.

3. Rowe J.M. Prognostic factors in adult acute lymphoblastic leukaemia. British Journal of Haematology 2010; 150: 389-405.

4. Chessells JM, Harrison CJ, Kempski H et al. Clinical features, cytogenetics and outcome in acute lymphoblastic and myeloid leukemia of infancy: report from MRC Childhood, Leukemia working party. Leukemia 2002; 16 : 776-84.

5. Silverman, L.B. Childhood Acute Lymphoblastic Leukemia: Currently Applied Prognostic Factors, International society of pediatric oncology 2010; 18-24.

6. Coustan-Smith E, Sancho J, Hancock ML et al. Clinical importance of minimal residual disease in childhood acute lymphoblastic leukemia. Blood 2000; 96: 2691-6.

7. Bene MC, Castoldi G, KnappW et al. European Group for the Immünological Characterization of Leukemia (EGIL): Proposals fort he immünological classification of acute leukemias. Leukemia 1995; 9: 1783-6.

8. Owen P. Smith and Ian M. Hann. Clinical features and therapy of lymphoblastic leukemia. Pediatric Hematology, Third Edition Robert J. Arceci, Ian M. Hann, Owen P. (eds). Smith Copyright by Blackwell Publishing Ltd 2006: 450-81.
9. Pieters R, Carroll WL. Biology and Treatment of Acute Lymphoblastic Leukemia. Pediatr Clin N Am 2008; 55: 1-20.

10. Schrappe $M$, Reiter A, Zimmermann $M$ et al. Long-term results of four consecutive trials in childhood ALL performed by the ALL-BFM study group from 1981 to 1995: Berlin-Frankfurt-Munster. Leukemia 2000; 14: 2205-22.

11. Noronha EP, Marinho HT, Thomaz EB et al. Immünophenotypic characterization of acute leukemia at a public oncology reference center in Maranhão, northeastern Brazil. Sao Paulo Med J 2011; 129: 392-401.

12. Schrappe M, Reiter A, Ludwig WD et al. Improved outcome in childhood acute lymphoblastic leukemia despite reduced use of anthracyclines and cranial radiotherapy: results of trial ALL-BFM 90. German-Austrian-Swiss ALL-BFM Study Group. Blood 2000; 95: 3310-22.

13. Arceci RJ, Hann IM, Smith OP. Clinical features and therapy of lymphoblastic leukemia. In Arceci RJ, Hann IM, Smith OP (eds). Pediatric Hematology. 3th ed Malden, Massechusetts Blackwell, 2006: 450-81.

14. Pui C-H, Evans WE. Treatment of acute lymphoblastic leukemia. N Engl J Med 2006; 354: 166-78.

15. Rego EM, Garcia AB, Viana SR et al. Characterization of acute lymphoblastic leukemia subtypes in Brazilian patients. Leuk Res 1996; 20: 349-55.

16. Dalia A, Salem Sherin M, Abd El-Aziz. Flow cytometric Immünophenotypic Profile of Acute Leukemia: Mansoura Experience; Indian J Hematol Blood Transfus 2012; 28: 89-96.

17. Uckun FM, Sensel MG, Sun L et al. Biology and treatment of children T lineage acute lymphoblastic leukaemia. Blood 1998; 91: 735-46.

18. Aric M, Schrappe M, Harbott J et al. Prednisone good response (PGR) identifies a subset of $\mathrm{t}(9 ; 22)$ childhood acute lymphoblastic leukemia (ALL) at lower risk for early leukemia relapse. Blood 1997; 90: 2494-8.

19. Lauten M, Möricke A, Beier R et al. Prediction of outcome by early bone marrow response in childhood acute lymphoblastic leukemia treated in the ALL-BFM 95 trial: differential effects in precursor B-cell and T-cell leukemia. Haematologica 2012; 97: 1048-56.

20. Möricke A, Reiter A, Zimmermann M et al. German-Austrian-Swiss ALLBFM Study Group. Risk-adjusted therapy of acute lymphoblastic leukemia can decrease treatment burden and improve survival: treatment results of 2169 unselected pediatric and adolescent patients enrolled in the trial ALL-BFM 95. Blood.2008; 111: 4477-89.

21. Uyttebroeck A, Suciu S, Laureys G et al. Treatment of childhood T-cell lymphoblastic lymphoma according to the strategy for acute lymphoblastic leukaemia, without radiotherapy: long term results of the EORTC CLG 58881 trial. Eur J Cancer 2008; 44: 840-6. 